\title{
The Brief Symptom Inventory:A validity-reliability Study of a Sample from Azerbaijan
}

\author{
Melek Kerimova ${ }^{1}$, Nermin Osmanli ${ }^{1}$ \\ ${ }^{1}$ School of Humanities and Social Sciences, Khazar University, Baku, Azerbaijan \\ Correspondence:MelekKerimova, School of Humanities and Social Sciences, Khazar University, Baku, Azerbaijan.
}

Received: September 21, 2016

Accepted: November 17, 2016

Online Published: November 20, 2016

doi:10.11114/jets.v4i12.2000

URL: http://dx.doi.org/10.11114/jets.v4i12.2000

\begin{abstract}
The aim of this research was to adapt Brief Symptom Inventory developed by Derogatis (1983) into Azerbaijani language. Data were collected from309 college students to determine psychometric properties of inventory. Samples in the study have been selected separately. The package programs of SPSS 18.0 and Lisrel 8.80 were used for the analysis of the data. The Cronbach's Alpha $(\alpha)$ internal consistency coefficient was calculated for the scale $(\alpha=.95)$ and for each subscale: Somatization $(\alpha=.80)$, Obsessive-Compulsive $(a=.70)$, Interpersonal Sensitivity $(\alpha=.65)$, Depression $(\alpha$ $=.81)$, Anxiety $(\alpha=.82)$, Hostility $(\alpha=.81)$, Phobic anxiety $(\alpha=.60)$, Paranoid ideation $(\alpha=.61)$ and Psychoticism $(\alpha$ $=.65)$. The 9 factor structure of the inventory was tested through CFA.
\end{abstract}

Keywords: brief symptom inventory, Azerbaijani culture, reliability, validity

\section{Introduction}

According to official data of Azerbaijan's State Statistics Committee, the country's youth population in the 14-29 age groups account for slightly over 2.6 million people or $28 \%$ of Azerbaijan's population (www.stat.gov.az). There has been an upward trend in the growth of neurological disorders among this group of population compared to previous years. It is considered that the war with Armenia and its implications, including internal displacement of the population and economic difficulties continue to impact the youth population. This has given rise to a need for tests and inventories that could be rapidly administered to evaluate the psychological symptoms among them. This study tests the validity and reliability of the Brief Symptom Inventory as an instrument that has been translated and adapted into many languages.

Recently, the importance of assessment of individuals with reliable and valid scales has increased in mental health. The self-reporting scales are specified as time saving, useful, practical and supportive in defining preventive approaches.

Brief Symptom Inventory (BSI) is a self-reporting scale, which measures nine psychological symptoms. BSI allows screening several psychological symptoms in a short time span. Therefore, it is used extensively in clinical evaluation and research. According to Medline, BSI has been employed in 260 studies since 2000. As Psycho info cited, this inventory is used in 1700 studies (Maanse Hoe \& John S.Brekke, 2008).

The BSI has been translated and adapted for different cultures, including into British (Francis, Rajan, \& Turner, 1990; Ryan, 2007), Italian (De Leo, Frisoni, Rozzini, \& Trabucchi, 1993), Turkish (Shahin \& Durak, 1994), Spanish (Aragón, Bragado, \& Carrasco, 2000; Ruipérez, Ibáñez, Lorente, Moro,Ortet, 2001; Pereda et al.,2007), Israeli (Canetti, Shalev, \& Kaplan, 1994; Gilbar, \& BenZur, 2002), Scottish (Schwannauer \& Chetwynd, 2007), Greek (Louitsiou-Ladd, Panayiotu\& Kokkinos) and Persian (P. Mohammadkhani, 2010), and used as a tool of valid and reliable measurement.

The translation and adaptation of BSI into Azerbaijani culture is important as a tool of data collection for field experts and for facilitating new research options. Moreover, as a country that has been affected by a war with Armenia and millions of refugees, Azerbaijan needs to analyze psychological problems among its population and preventive methods. Therefore, the aim of the study is to adapt easily defined and practical BSI scale for the evaluation of general distress among young peoples.

In this article, the authors report on the psychometric properties and dimensional structure of BSI Azerbaijani version 


\section{Method}

\subsection{Sample}

Data collected from the Khazar University in Azerbaijan for academic year 2014-2015. The sample of the study consists of 309 university students, who were recruited by random cluster sampling. Participants ranging in age from 17 to 28 years old $(M=19.64 ; S D=1.73)$ were included in the study. Out of 309 participants men consist of $(N=104) 37.7 \%$, women $(\mathrm{N}=205) 66.3 \%$.

\subsection{Data Collection Tools}

In order to obtain the demographic data on the participants, the authors developed "Personal Information Questionnaire".

\subsection{Brief Symptom Inventory}

The BSI, a short form of the Symptom Checklist-90 (Derogatis, 1977), is a 53-item self-report measure of symptoms of psychological distress (Derogatis, 1993).The BSI is prevalent in the studies among adults. The instrument consists of 9 subscales ('Somatisation', 'Obsessive-Compulsive', 'Interpersonal Sensitivity', 'Depression', 'Anxiety', 'Hostility', 'Phobic Anxiety', 'Paranoid Ideation' and 'Psychoticism') and 3 global indices (General Severity Index (GSI),the Positive Symptom Distress Index (PSDI)and the Positive Symptom Total (PST). The items consist of physical and psychological symptoms that occurred during the last week (Derogatis and Melisaratos, 1983). The BSI is a Likert-type scale, which rates items on a 5-point system of distress (0-4), ranging from 'not at all' to 'extremely'.

Three different studies show that the internal consistency coefficient of 9 subscales ranged from .71 to .85 . Correlation coefficients as a result of the test retest reliability study ranged as follows: $.68-.91$ for the 9 subscale, .90 for the GSI, .87 for the PSDI, and .80 for the PST (Derogatis \& Spencer, 1982, Şahin \& Durak, 1994).

\section{Procedure}

\subsection{Translation}

The original scale was translated into the Azerbaijani language by two bilinguals, of both Azerbaijani and English languages, as experts of psychologists. Then, the translated scale was administered on 25 students from various departments and revised based on feedback from the individuals, to complete the process.

\subsection{Data Analysis for CFA}

First correlations among the BSI scales were computed as Cronbach alpha coefficients for the full global severity index and each of its nine subscales to examine the internal reliability of the scale. The goodness-of-fit indices for the model tested through CFA was determined with the help of $\chi^{2}$ (Chi-Square Goodness-of-Fit), GFI (Goodness-of-Fit Index), AGFI (Adjusted Goodness-of-Fit Index), CFI (Comparative Fit Index), NFI (Normed Fit Index), NNFI (Not-Normed Fit Index), RMR (Root Mean Square Residuals), SRMR (Standardized Root Mean Square Residuals) and RMSEA (Root Mean Square Error of Approximation) indices. For the analysis of the data, the package programs of SPSS 18.0 and Lisrel 8.80 (Jöreskog \& Sörbom, 2006) were used for descriptive statistics and confirmatory factor analysis, respectively.

\section{Findings}

\subsection{Findings Regarding the Adaptation of Brief Symptom Inventory}

Table 1. Means(M) and standard deviations(SD) by gender for the Azerbaijani version of the BSI

\begin{tabular}{|c|c|c|c|c|c|c|c|}
\hline \multirow[t]{2}{*}{ Scale } & \multicolumn{2}{|r|}{ Total $(\mathrm{N}=309)$} & \multicolumn{2}{|c|}{$\begin{array}{l}\text { Male } \\
(\mathrm{N}=104,33.7 \%)\end{array}$} & \multicolumn{2}{|c|}{$\begin{array}{l}\text { Female } \\
(\mathrm{N}=205,66.3 \%)\end{array}$} & \multirow[t]{2}{*}{$\mathbf{P}$} \\
\hline & $\mathbf{M}$ & SD & $\mathbf{M}$ & SD & M & SD & \\
\hline SOM & 1.28 & .65 & 0.80 & .65 & 1.03 & .79 & $<.05$ \\
\hline $\mathrm{OCB}$ & 1.55 & .78 & 1.48 & .78 & 1.57 & .77 & ns \\
\hline I-S & 1.44 & .94 & 1.30 & .87 & 1.51 & .96 & ns \\
\hline DEP & 1.31 & .90 & 1.30 & .84 & 1.32 & .92 & ns \\
\hline ANX & .96 & .76 & 1.39 & .89 & 1.55 & .95 & ns \\
\hline HOS & 1.50 & .94 & 1.33 & .98 & 1.50 & .99 & ns \\
\hline PHOB & 1.45 & .99 & .88 & .73 & .86 & .68 & ns \\
\hline PAR & .87 & .70 & 1.46 & .81 & 1.59 & .84 & ns \\
\hline PSY & 1.55 & .83 & 1.22 & .75 & 1.18 & .78 & ns \\
\hline GSI & 1.20 & .77 & 1.20 & 0.60 & 1.32 & 0.67 & ns \\
\hline
\end{tabular}


Table 2. Mean scores on the BSI in different studies

\begin{tabular}{|c|c|c|c|c|c|c|}
\hline Subscales & $\begin{array}{l}\text { British } \\
(\mathrm{N}=376) \\
\text { community } \\
\text { sample } \\
\text { (Francis, } \\
\text { Rajan\& } \\
\text { Turner, 1990) } \\
\text { M (SD) }\end{array}$ & $\begin{array}{l}\text { Scottish } \\
(\mathrm{N}=459) \\
\text { psychologist } \\
\text { sample } \\
\text { (Schwannauer } \\
\text { \&Chetwynd, } \\
\text { 2007) } \\
\text { M (SD) }\end{array}$ & $\begin{array}{l}\text { Greek } \\
(\mathrm{N}=818) \\
\text { community } \\
\text { sample } \\
\text { (Loutsiou-Ladd, } \\
\text { Panayiotou,\& } \\
\text { Kokkinos,2008) } \\
\text { M (SD) }\end{array}$ & $\begin{array}{l}\text { Israil(N=510) } \\
\text { community } \\
\text { sample } \\
\text { (Gilbar\&Ben-Z } \\
\text { ur, 2002) } \\
\text { M (SD) }\end{array}$ & $\begin{array}{l}\text { Iranian } \\
(\mathrm{N}=354) \\
\text { depressed } \\
\text { patients } \\
\text { (Mohammadkha } \\
\text { ni, 2010) } \\
\mathrm{M}(\mathrm{SD})\end{array}$ & $\begin{array}{l}\text { Psychiatric } \\
\text { Outpatients } \\
(\mathrm{N}=1002) \\
\text { (Derogatis\& } \\
\text { MelisaratoS, } \\
\text { 1992) } \\
\text { M (SD) }\end{array}$ \\
\hline Somatization & $0.43(0.57)$ & $1.09(0.94)$ & $0.77(.79)$ & $.62(.68)$ & $1.34(.94)$ & $.83(.79)$ \\
\hline $\begin{array}{l}\text { Obsessive-com } \\
\text { pulsive }\end{array}$ & $0.59(0.63)$ & $1.69(1.08)$ & $1.34(.83)$ & $.94(.79)$ & $1.70(.85)$ & $1.57(1.00)$ \\
\hline $\begin{array}{l}\text { Interpersonal } \\
\text { sensitivity }\end{array}$ & $0.58(0.72)$ & $1.75(1.22)$ & $1.12(.90)$ & $.68(.71)$ & $1.53(.96)$ & $1.58(1.05)$ \\
\hline Depression & $0.42(0.65)$ & $1.68(1.14)$ & $.92(.81)$ & $.70(.69)$ & $1.83(1.01)$ & $1.80(1.08)$ \\
\hline Anxiety & $0.45(0.60)$ & $1.90(1.13)$ & $1.06(.85)$ & $.85(.71)$ & $1.42(.91)$ & $1.70(1.00)$ \\
\hline Hostility & $0.44(0.60)$ & $1.30(1.14)$ & $.93(.78)$ & $.72(.70)$ & $1.18(.84)$ & $1.16(.93)$ \\
\hline Phobic anxiety & $0.24(0.50)$ & $1.21(1.16)$ & $.53(.64)$ & $.46(.61)$ & $.90(.78)$ & $.86(.88)$ \\
\hline $\begin{array}{l}\text { Paranoid } \\
\text { ideation }\end{array}$ & $0.54(0.65)$ & $1.29(1.06)$ & $1.14(.83)$ & $.91(.78)$ & $1.52(.92)$ & $1.14(.95)$ \\
\hline Psychotism & $0.27(0.48)$ & $1.27(0.98)$ & $.72(.70)$ & $.57(.62)$ & $1.37(.84)$ & $1.19(.87)$ \\
\hline GSI & $0.44(0.47)$ & $1.47(0.85)$ & $.94(.65)$ & $.72(.59)$ & $1.32(.70)$ & $1.32(.72)$ \\
\hline
\end{tabular}

Descriptive statistics of participants are presented in Table 1. Out of 309 participants $37.7 \%(\mathrm{~N}=105)$ were male and $66.3 \%$ were female $(\mathrm{N}=204)$. The differences between the men and women were evaluated with a series of Independent Samples t Tests. Except for the "Somatisation" subscale, none of the differences between male and female respondents were significant at the level of $p<.05$. As can be seen from the Table 1 and Table 2 , mean scores were found to be higher than in other countries, especially for community samples.

Table 3. Pearson Correlations Coefficients among the nine subscales and GSI

\begin{tabular}{|c|c|c|c|c|c|c|c|c|c|}
\hline Scales & SOM & OC & IS & DEP & ANX & HOS & PHOB & PAR & PSY \\
\hline$\overline{\text { SOM }}$ & - & .57 & .56 & .53 & .71 & .55 & $\begin{array}{l}.61 \\
\end{array}$ & .46 & .51 \\
\hline OC & .57 & - & .56 & .63 & .66 & .53 & .55 & .55 & .58 \\
\hline IS & .46 & .56 & - & .68 & .67 & .48 & .55 & .63 & .61 \\
\hline DEP & .53 & .63 & .68 & - & .74 & .57 & .62 & .63 & .70 \\
\hline ANX & .71 & .66. & .67 & .74 & - & .66 & .70 & .65 & .66 \\
\hline HOS & .55 & .53 & .48 & .57 & .65 & - & .50 & .56 & .55 \\
\hline РНОВ & .61 & .55 & .55 & .62 & .70 & .50 & - & .57 & .63 \\
\hline PAR & .46 & .55 & .63 & .63 & .65 & .56 & .57 & - & .67 \\
\hline PSY & .51 & .58 & .61 & .70 & .66 & .54 & .63 & .67 & - \\
\hline GSI & .64 & .59 & .63 & .61 & .68 & .59 & .60 & .56 & .58 \\
\hline
\end{tabular}

As presented in Table 3 correlations among the BSI sub-factors and Global Severity Index (GSI) were found to be significantat $\mathrm{p}<.001$.

\subsection{Internal Consistency}

Cronbach's alpha internal consistency coefficient for the Global Severity Index (GSI) were identified as $\alpha=.95$. Internal consistency coefficient for each subscale was calculated as follows: Somatization $(\alpha=.80)$, Obsessive-Compulsive (a $=.70)$, Interpersonal Sensitivity $(\alpha=.65)$, Depression $(\alpha=.81)$, Anxiety $(\alpha=.82)$, Hostility $(\alpha=.81)$, Phobic anxiety $(\alpha$ $=.60)$, Paranoid ideation $(\alpha=.61)$ and Psychoticism $(\alpha=.65)$.

\subsection{Confirmatory Factor Analysis (CFA)}

The BSI structure was made up of 53 and nine-factor items. As the data set demonstrated a normal distribution, the authors used parameter estimation method Maximum Likelihood Method and the data matrix Covariance Matrix in CFA.

The $\mathrm{t}$-value for each indicator in the scale is suggested to be out of the range of $+2.58(p<.01)$. The $t$-value for each item was higher than +2.58 . The error variance was lower than 90 . Thus, the error variance was not much high (Kline, 2011; Raykov \& Marcoulides, 2006; Tabachnick \& Fidell, 2007). 


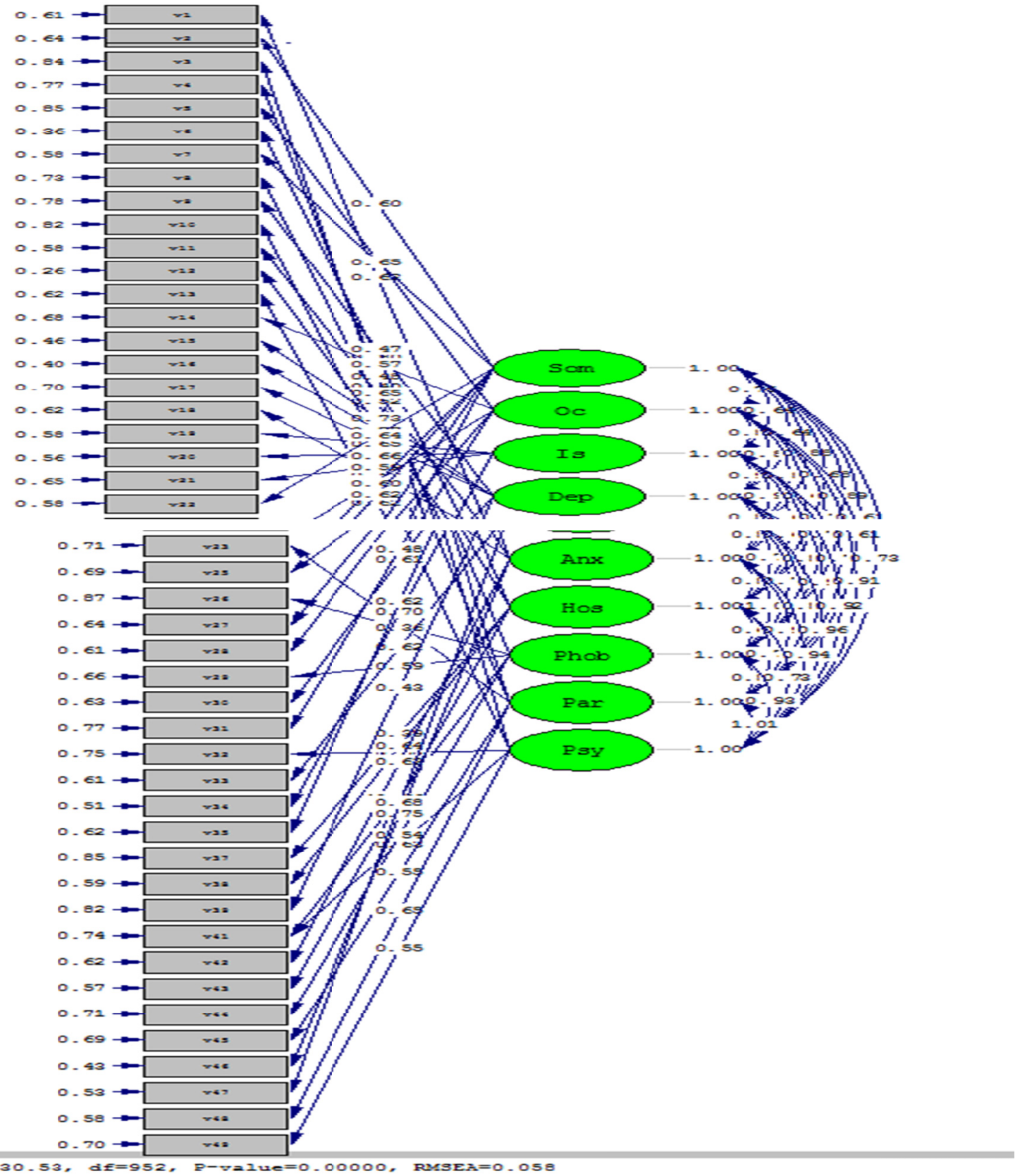

Figure 1. Standardized Path Diagram

The traditional measure for structural equation modeling is Chi-Square. First value to be examined is $p$ level for the Chi-Square $\left(\chi^{2}\right)$. An insignificant result at a 0.05 threshold shows good fit (Hooper et al. 2008). According to the results, $\mathrm{p}$ value is significant at 0.05 level. However, significant is normal for large sizes of samples. Therefore, it is suggested thatother fit indices should be evaluated too (Tabachnick \& Fidell, 2007). The Chi-Square value was found as $\chi^{2}=$ 1930.52and degree of freedom as $\mathrm{df}=952$. It is perfect fit if the ratio of $\chi^{2} / \mathrm{df}(2.02)$ is lower than 3 (Kline, 2011; Tabachnick \& Fidell, 2007).

When the fit statistic of Root Mean Square Error of Approximation (RMSEA) was analyzed, the fit index was found as .058. It shows good fit providing that RMSEA $\leq .08$ (Hooper, et al. 2008). The goodness of fit index (GFI) was determined to be (.79) smaller than .90 which means poor fit (Hooper et al, 2008; Hu \& Bentler, 1999). Root mean square residual (RMR) and standardized root mean square residual (SRMR) were found as: $\mathrm{RMR}=.080$ and $\mathrm{SRMR}=$. 059. Suitability index values less than .05 were accepted as perfect fit and less than .08 good fit (Brown, 2006; Hu \& Bentler, 1999). When examined, the Non-Normed Fit Index (NNFI) CFI (Comparative fit index), NNFI and CFI were found .97. Higher suitability values than .95 represent perfect fit (Hu \& Bentler, 1999; Tabachnick \& Fidell, 2007; Thompson, 2008). 
As a result, perfect or good fit values were found for all fit indices except for the GFI. This indicates that the nine-dimensional structure of scale was confirmed.

\section{Conclusion and Discussion}

In this study, "Brief Symptom Inventory" developed by Derogatis (1993), was adapted into the Azerbaijani language. In this sense, instead of developing a new measure, it was considered expedient based on cultural and language similarities to use a measure with validity and reliability proven in many other studies. As this research project is the first and would be a pioneer for future studies, it is expected to significantly contribute, particularly to the national scholarly literature in psychology.

Students were randomly selected from different majors, through stratified sampling. Data were obtained from 309 students in the sample of the Khazar University.

The Cronbach's Alpha $(\alpha)$ internal consistency coefficient of the scale was calculated as $\alpha=.95$. Reliability coefficient of 9 sub-factors, regarding the scale, was found as follows: $\alpha=.80$ for Somatisation, $\alpha=.70$ for Obsessive Compulsive, $\alpha=.65$ for Interpersonal Sensitivity, $\alpha=.81$ Depression, $\alpha=.82$, Anxiety, $\alpha=.81$, Hostility, $\alpha=.60$ for Phobic Anxiety, $\alpha=.61$ for Paranoid Ideation. Additionally, the differences in gender attitudes in Somatisation subscale could have resulted from cultural manners. Based on these results, the scale structure is shown to be robust enough to be used in Azerbaijan.

The mean gained from subscales are higher than the community sample. (Francis, V. M., Rajan, P., \& Turner, N. 1990) This results shows that from not everyone benefits the mental services and it is not widely spread.

The nine factor structure of the scale was tested through CFA. As a result of CFA, the fit indices were generally observed as good or perfect in 9 subscale BSI. Although international literature presents some findings on these factors, they may have different effect levels based on cultural differences. In this context, the BSI adapted within this study could be used as a diagnosis tool in clinical settings, despite the fact that required data was garnered from a university sample. Thus, investigating various demographic variables in different sample groups in Azerbaijan (presumably in clinical sample) and evaluating the results following this process would present data that are more robust. Another limitation of this study is the fact that data was collected from one university. Even though, the number of sample was enough, a more comprehensive study could be conducted in Azerbaijan to reveal the psychological distress among adults with more clarity. The focus of this research paper has been on developing a measurement tool tailored to Azerbaijan. Although, dearth lack of empirical studies in Azerbaijan prevented data collection from universities, introducing a measurement tool through this study will contribute to an increase in the scope of future empirical research in the country.

\section{References}

Boulet, J., \& Boss, M. W. (1991). Reliability and validity of the Brief Symptom Inventory. Psychological Assessment: A Journal of Consulting and Clinical Psychology, 3(3), 433. https://doi.org/10.1037/1040-3590.3.3.433

Brown, T. A. (2006). Confirmatory factor analysis for applied research. New York, NY: Guilford.

Browne, M. W., \& Cudeck, R. (1993).Alternative ways of assessing model t. KA Bollen \& JS Long.

Canetti, L., Shalev, A. Y., \& De-Nour, A. K. (1994). Israeli adolescents' norms of the Brief Symptom Inventory (BSI). Israel journal of psychiatry and related sciences.

Cheng, D., Leong, F. T., \& Geist, R. (1993). Cultural differences in psychological distress between Asian and Caucasian American college students. Journal of Multicultural Counseling and Development, 21(3), 182-190. https://doi.org/10.1002/j.2161-1912.1993.tb00598.x

Cochran, C. D., \& Hale, W. D. (1985).College student norms on the Brief Symptom Inventory. Journal of Clinical Psychology. https://doi.org/10.1002/1097-4679(198511)41:6<777::AID-JCLP2270410609>3.0.CO;2-2

Çokluk, Ö.,Şekercioğlu, G., \&Büyüköztürk, Ş. (2012). Sosyalbilimleriçinçokdeğişkenli SPSS ve LİSREL uygulamaları (2.Bask1). PegemAkademiYaylnlart.

Derogatis, L. R., \& Melisaratos, N. (1983). The Brief Symptom Inventory: An Introductory report. Psychological medicine, 13(03), 595-605. https://doi.org/10.1017/S0033291700048017

Derogatis, L. R., \& Spencer, M. S. (1982). The Brief Symptom Inventory (BSI): Administration, scoring, and procedures manual-I. Baltimore, MD: Johns Hopkins University School of Medicine, Clinical Psychometrics Research Unit

Derogatis, L. R., \& Spencer, P. M. (1993). Brief symptom inventory: BSI. Upper Saddle River, NJ, USA::Pearson. 
Francis, V. M., Rajan, P., \& Turner, N. (1990). British community norms for the Brief Symptom Inventory. British Journal of Clinical Psychology, 29(1), 115-116.https://doi.org/10.1111/j.2044-8260.1990.tb00857.x

Gilbar, O., \& Ben-Zur, H. (2002). Adult Israeli community norms for the Brief Symptom Inventory (BSI).International Journal of Stress Management, 9(1), 1-10. https://doi.org/10.1023/A:1013097816238

Hale, W. D., Cochran, C. D., \& Hedgepeth, B. E. (1984). Norms for the elderly on the brief symptom inventory.Journal of Consulting and Clinical Psychology, 52, 321-322. https://doi.org/10.1037/0022-006X.52.2.321

Hambleton, R. K., \&Patsula, L. (1999). Increasing the validity of adapted tests: Myths to be avoided and guidelines for improving test adaptation practices. Journal of Applied Testing Technology, 1(1), 1-13.

Hoe, M., \& Brekke, J. S. (2008). Cross-Ethnic Measurement Invariance of the Brief Symptom Inventory for Individuals with Mental Illness. Social Work Research, 32(2), 71-78. https://doi.org/10.1093/swr/32.2.71

Hooper, D., Coughlan, J., \& Mullen, M. (2008). Structural equation modeling: Guidelines for determining model fit. Articles, 2.

Hu, L. T., \& Bentler, P. M. (1999). Cutoff criteria for fit indexes in covariance structure analysis: Conventional criteria versus new alternatives. Structural equation modeling: a multidisciplinary journal, 6(1), 1-55. https://doi.org/10.1080/10705519909540118

Internet World Stats. (2015). Retrieved from http://www.internetworldstats.com/stats.html

Kerimova, M., \& Gunuc, S. (2016). Adaptation of Internet Addiction Scale in Azerbaijani Language: A Validity-Reliability and Prevalence Study. Journal of Education and Training Studies, 4(1), 39-48.

Kline, R. B. (2011). Principles and practice of structural equation modeling (3th ed.) New York: The Guilford Press.

Lang, A. J., Norman, S. B., Means-Christensen, A., \& Stein, M. B. (2009). Abbreviated brief symptom inventory for use as an anxiety and depression screening instrument in primary care. Depression and Anxiety, 26(6), 537-543.

Leo, D., Frisoni, G. B., Rozzini, R., \& Trabucchi, M. (1993). Italian community norms for the Brief Symptom Inventory in the elderly. British journal of clinical psychology, 32(2), 209-213. https://doi.org/10.1111/j.2044-8260.1993.tb01045.x

Loutsiou-Ladd, A., Panayiotou, G., \& Kokkinos, C. M. (2008). A review of the factorial structure of the Brief Symptom Inventory (BSI): Greek evidence. International Journal of Testing, 8(1), 90-110. https://doi.org/10.1080/15305050701808680

Melek, K. (2000). Some psychological symptoms in high school students in respect to some variables", Master Thesis, Hacettepe University.

Parvaneh, M., Keith, S., Dobson, M. A., \& Fatemeh, H. G. (2010). Psychometric properties of the Brief Symptom Inventory in a sample of recovered Iranian depressed patients. International Journal of Clinical and Health Psychology ISSN 1697-2600, 1(10), 541-551.

Pereda, N., Forns, M., \&Peró, M. (2007).Dimensional structure of the Brief Symptom Inventory with Spanish college students. Psicothema, 19(4), 634-639.

Ramírez, N. A., Álvarez, M. C. B., \& Galán, I. C. Fiabilidad Y Estructura Factorial Del «InventarioBreve De Síntomas» (Brief Symptom Inventory, Bsi) En Adultos

Ryan, C. (2007). British outpatient norms for the Brief Symptom Inventory. Psychology and Psychotherapy: Theory, Research and Practice, 80(2), 183-191. https://doi.org/10.1348/147608306X111165

Sahin, N., \& Durak, A. (1994). A study of the Brief Symptom Inventory in Turkish Youth. [Turkish]. Turk PsikolojiDergisi, 9(31), 44-56.

Sahin, S. (2011).The Relationship between Instructional Leadership Style and School Culture (Izmir Case). Educational Sciences: Theory and Practice, 11(4), 1920-1927.

Slaughter, J., Johnstone, G., Petroski, G., \&Flax, J. (1999). The usefulness of the Brief Symptom Inventory in the neuropsychological evaluation of traumatic brain injury. Brain Injury, 13(2), 125 -130.

Statistics, A. (2010). Retrieved from http://www.stat.gov.az/menu/6/statistical_yearbooks/

Tabachnick, B. G., \&Fidell, L. S. (2007). Experimental designs using ANOVA. Thomson/Brooks/Cole.

Watson, D. C., \&Sinha, B. K. (1999). A cross-cultural comparison of the Brief Symptom Inventory. International Journal of Stress Management, 6(4), 255-264. 


\section{QISA SIMPTOM TESTI (QST)}

Aşağıda zaman zaman hərkəsdə görülə bilən sıxıntılar sıralanmaşdır. Xahiş olunur hər birini diqqətlə oxuyun. Sonra bu vəziyyətin size bugün də daxil olmaq şərtiilə son 1 ay ərzində nə qədər narahat etdiyini qeyd edin.

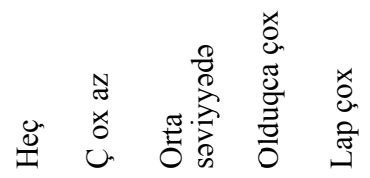

1. Hirslilik, içinin titrəməsi

2. Baş gicəllənməsi və bayılma

3. Hər hansı bir insanın fikirlərinizə hakim olacağı hissi

4. Problemlərinizdə başqalarını günahlandırmaq

5. Hadisələri yada salmaqda çətinlik

6. Asanlıqla hirslənib özündən çıxma

7. Sinə və ürək hissəsində ağrilar

8. Küçədə və açıq ərazilərdə qorxu hissi

9. Həyatınıza son vermə fikirləri

10. İnsanların çoxuna inanılmayacağı hissi

11. İștahanın pozulması

12. Heç bir səbəbi olmayanani qorxular

13. Nəzarət edə bilmədiyiniz özündən çıxmalar (hirs partlayışları)

14.Başqalarıyla birlikdə olanda belə təklik hiss etmə

15.Görüləcək işləri ertələmə hissi

16. Yalqizliq hissi

17. Özünü kefsiz, kədərli hiss etmə

18. Heçnə ilə maraqlanmamaq

19. Özünü kövrək hiss etmə

20. Asanlıqla incimə, dəymədüşərlik

21. İnsanların size sevmədiyinə,sizə pis davrandığına inanma

22. Özünü digər insanlardan əksik hiss etmə

23. Mədə ağrıları, ürək bulanma

24. Digər insanların sizi izlədiyi ya da haqqınızda danışdığı hissi

25. Yuxuya getmədə çətinlik

26. Gördüyünüz işi bir ya da bir neçə dəfə yoxlamaq

27. Qərar verə bilməmək

28. Avtobus,qatar, metro kimi minik vasitələrinə minmə qorxusu

29. Nəfəs almada çətinlik

30. Soyuq və istilik basması

31. Sizi qorxudan müəyyən davranış,yer və əşyalardan qaçma hissi

32. Beyninizin bomboş qalması

33. Bədəninizin bəzi yerlərində iynələnmə halı

34. Səhvlərinizə görə cəza verilməsi fikri

35. Gələcəklə əlaqədar ümutsizlik duyguları

36.Diqqəti cəmləşdirməkdə çətinlik

37. Bədənin bəzi bölgələrində zəiflik,gücsüzlük

38.Özünü gərgin və narahat hiss etmə

39.Ölmə və ölüm üzərinə düşüncələr

40. Bir başqasını vurmaq,zərər vermək,yaralamaq hissi

41. Otrafdaki nələri isə qurıb ,tökmə istəyi

42. Digər insanların yanında ikən səhv birşey etməməyə çalışmaq
43. Çox insan olan məkanda narahatçılıq hissi

44. Başqa insanlara heç yaxınlıq hiss etməmə

45. Dəhşət və panica hissi

46. Tez-tez mübahisəyə girmək

47. Tək qalandar hirslilik hissi

48. Başqalarının size uğurlarınıza görə qiymətləndirməmələri

49. Özünü çox narahat hiss etmə

50. Dəyərsizlik hissi

51. İcazə verəcəyiniz təqdirdə insanları sizdən istifadə edəcəyi fikri

52. Gunahkarlıq hissi

53. Ağlınızla əlaqədar tərəddüdlər.

\section{$(\mathrm{cc}) \mathrm{EY}$}

This work is licensed under a Creative Commons Attribution 3.0 License. 